\title{
TRANSFER OF MUSICAL ABILITIES AND POSSIBLE REFLECTIONS OF TEACHING CONTENT
}

\author{
Dr. Cvetković Crvenica Jelena, University of Niš, Faculty of Arts, Niš, Serbia \\ E-mail: lesnjakjelena@gmail.com \\ MA Jovanović Milica, University of Niš, Faculty of Arts, Niš, Serbia \\ E-mail: milica.jovanovic37@yahoo.com
}

\section{A R T I C L E I N F O \\ Original Research \\ Received: July, 19.2019. \\ Revised: August, 12.2019. \\ Accepted: August, 20.2019. \\ doi:10.5937/IJCRSEE1902087C \\ UDK \\ 316.644-057.875:[371.3::784.9(497.11)}

Keywords:

transfer,

musical abilities,

musical pedagogy,

theory,

performing practice.

\begin{abstract}
A B S T R A C T
The paper aims to indicate the direct link between the development of knowledge, skills and music abilities in the pedagogical practice which encourages concrete cognitive, psychomotor and affective processes that lie in basis of the transfer of learning. We analyzed the attitudes of the students of the Department of Music Art from the Faculty of Arts in Niš according to musical skills acquired in solfeggio teaching, in the context of their impact on the instrumental performance. Assuming that advancement of musical skills acquired in solfeggio teaching directly affects the field of instrumental performance and leads to the development of music potential, or development of musical abilities, at the level of sensory abilities, as well as at the level of understanding musical structures, the research, which established the student attitudes to evaluating different components of instrumental performance; correlation of solfeggio and instrumental teaching; importance of work on some elements in the solfeggio teaching and evaluating expressive elements in relation to the technical skills in the solfeggio teaching, was conducted. The results of conducted research confirmed basic hypothesis that students express high awareness of the narrow connectivity of solfeggio and instrumental teaching, equally evaluating work in all areas of solfeggio teaching. Simultaneously, they indicate the importance of educational experience in shaping the standpoints of students who showed positive attitudes about a possible reflection of the solfeggio teaching content and skills that are acquired in it, as well as there's a high degree of the use of skill acquired in solfeggio teaching in instrumental performance.
\end{abstract}

() 2019 IJCRSEE. All rights reserved.

\section{INTRODUCTION}

Education of musicians, with respect for all the specificity that affect the outcome of learning in many different areas, includes two basic aspects: Acquiring and storing music information and experiences on one hand and develop of musical skills on the other. The adoption of music knowledge offers an individual opportunity for musical development, while development of musical skills involves

Corresponding Author

Dr. Cvetković Crvenica Jelena, University of Niš, Faculty of Arts, Niš, Serbia

E-mail: lesnjakjelena@gmail.com

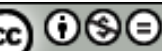

This work is licensed under a Creative Commons Attribution - NonCommercial - NoDerivs 4.0. The article is published with Open Access at www.ijcrsee.com the integration of the cognitive and psychomotor area (Klemp, 2010). Understanding of music and musical language is mostly associated with theoretical music disciplines and it comes to the cognitive area. Everything that we usually call playing or singing techniques can be classified into the psychomotor area. In music education the role of affective, where it comes to the aesthetic education, the development of the ability of critical evaluation of musical content and differentiation artistic of non-artistic, with individual development of artistic personality, is highlighted. According to Blum's taxonomy of educational aims, adopted by the American Psychological Society at the 1956 convention, and in the 1990s, in accordance with the new educational requirements, the results of general education were categorized into three related areas: cognitive area - related to knowledge acquisition; affec- 
tive area - which refers to the attainment of attitudes; psychomotor area - which refers to the acquisition of skills (Cvetković Crvenica and Miletić, 2019).

In a group of cognitive musical subjects that to a lesser extent include psychomotor area, we can classify: Solfeggio, Harmony, Polyphony, Musical forms, History of music, Composition, Music pedagogy, Musical instruments. Psychomotor subjects with a big share of the cognitive and affective are all instrumental and singing subjects, chamber and orchestral musicianship, choir, conducting, score playing and etc. Here it comes to the principle division of music education on the socalled theoretical and instrumental programs, and traditionally a variety of content intensity of theoretical subjects for, for example, theoreticians and performers. At the same time, as solfeggio educators, we are facing the eternal dilemma - what is Solfeggio, and what that subject teaches us?

What is Solfeggio?

The subject Solfeggio as a musicalpedagogical discipline has its educationallearning and functionally-practical aims that are truncated on the process of music literacy, the process of setting specific sound performance, acquisition the skill of voice reproduction of the score, understanding, memorizing and recording musical content. Solfeggio is the subject that by mastering small forms, leads us from intellection trough knowledge to comprehension, acquisition, understanding and development of a musical thought, which is considered to be the highlight of cognitive abilities. Understanding, as the inclusion of the new and unknown in a circle of old and familiar, leads to the knowledge that must be permanently and functionally to precede the thinking - thought process of establishing functional relationships. Solfeggio is mandatory subject from the beginning to the end of the music education and involves the adoption of the basic facts of music grammar. It is the subject that involves intelligence, determined by the knowledge fund developing levels, a good musical hearing, attention, concentration and talent. Stratification and complexity of musical art directly reflects on the complexity of solfeggio teaching. The adoption of terms, phenomena and the rules of music are achieved through the process of working on music literacy and later, through correlation of solfeggio teaching with instrumental teaching, but also counterpoint, harmony, musical forms and styles.

Complex cognitive process of adopting a music language ranges from the adoption of the individual musical terms to the ability of standalone analysis of the musical piece or music composing.

The aim of teaching is to direct musical knowledge of every instrumentalist to understanding music language, while, on the other hand, the content of theoretical subjects directs more towards practical, performance outcome.

In the initial levels of education can be talking about separate areas until later the area of understanding composition, virtuoso technical performance and built aesthetically attitude towards composition merge.

Specifically, in solfeggio teaching gradually stratification of relations of musical horizontal and vertical from simple to virtuoso is achieved through gradual movement from theoretical to practice, and it is best reflected in the two disciplines - dictation recording and singing prima vista examples. The first time reading the score is called Sight-reading by musicians (ital. prima vista which means at first glance).

More precisely, these two disciplines in a small form contain above mentioned levels, from hear recognition of intonation and rhythmic terms to their use represent the highest level of cognitive understanding music language (score), and they're almost not associated with the level of playing technique.

During these processes, two pedagogical orientations are always present: one, which puts the emphasis on empowering music vocabulary by practicing melodic / rhythmic / harmonic and technical elements, and the other, that puts focus on understanding music flow and content, expressivity and musically performance (Bogunović and Vujović, 2012). Sight reading can be defined as "the ability of transfer music symbols and marks in interpretation during a strict time limit" (Stauffer, 2005:21). The ability to sight read represents a reliable method of auditive internalization. When this skill is established, acquired auditive knowledge can be transferred to the instrument. Surveys have shown that exercise of prima vista examples leads to the skill improvement in every aspect of music (Beck, Surnami and Lewis, 2004: 5). To establish a connection between the performance and auditive skills, the understanding, which is highlighted as a comprehensive request of musical interpretation, is necessary.

Understanding is achieved through the three main activities: Improvisation and playing by ear, memory and kinesthesia. Impro- 
visation helps to understand the role between the active-hearing perception and intellection. The skill of improvisation, thereby, depends on the effective use of memory. Musical memory, as skill integrated with the development process of musical involves long-term ability of maintenance and recognition of music material which was previously experienced by perception (Cvetković-Crvenica, 2017). This skill is improved through perception and dictations.

\section{learning}

Musical knowledge and transfer of

Given the fact that subject Solfeggio represents a combination of practical and theoretical elements, concrete practical and abstract intellectual skills, the existence of potential for their transfer and use in different situations is necessary. Regarding this, the question arises - weather, and to what extent, the skills acquired in the solfeggio teaching function as a predictor of success in other musical areas, in particular the field of instrumental performance?

Transfer of learning (Term origin: from the Latin verb transferre - to transmit. To transmit means the transfer of the effect of one learning to another learning or activity; it is the use of previously acquired experience, or the repetition of certain behaviors in new situations.) is considered a base of reflective and abstract thought (Haskell, 2001) which overcomes almost all learning domains and it happens when the skills acquired in a particular area generalize on the new areas or enhance the general cognitive abilities (Sala and Gobet, 2017). The transfer of learning occurs when a person applies knowledge or skills taught in one context to a new context. The development of students' transversal competences is directly related to the use of the cognitive abilities for learning and interpreting knowledge developed to the level of skills (Tsankov, 2017). Researchers who are interested in the transfer of are initially guided by theories that highlight the similarities between the initial experience of learning and subsequent learning. The transfer is seen as the desirable goal in the process of learning today, and the music is one of the specific aspects of this complex and a broad research field.

Although researches of music abilities are carried out decades ago, regularly tracking their development in educational practices requires further research. In order to find out the possibility of transferability of musical skills acquired in the solfeggio teaching in the frame of instrumental teaching, we designed the questionnaire that reflects the attitudes of students according to certain areas of work in the solfeggio teaching and their influence on instrumental performance.

The paper represents an interdisciplinary research which aims to put in relationship theoretical-practical access of music pedagogues in solfeggio teaching based on methods, techniques and procedures of acquiring specific aspects of musical performance, with other theoretical and practical subjects and cognitive aspect of understanding and awareness as an integrated part of musical training.

This widely concept includes the entire skill complex, starting with sight reading, performing music, playing by heart and ear and improvisation (McPherson, 1997) to the entire spectrum of professional and personal skills including hearing, cognitive, technical, musicalexpressive, performing and learning skills (Hallam, 2006). Since the studying of music includes long periods of focused attention, every day practice, musical notation reading, memorizing long music units, learning about different musical structures, acquiring technical skills and emotional expression during performance, there are a number of reasons that affect the uniqueness of above mentioned transfers. Connectivity of the success of knowledge, playing and singing points to the transfer of musical knowledge and skills from one area of musical competencies to the other and accumulation of those competencies.

This combination of experiences can have a positive impact on the cognition, especially during childhood, when the brain development is high plastic and sensitive for the impact of the environment (Schellenberg, 2004). The conclusion exported out of this is that musical knowledge can be acquired only with actively engagement. The active position of the students is emphasized in order to improve their own abilities and also the quality of teaching (Galustyan, 2017). And while for to sing a crucial is level of musical skills, students can overcome playing by adoption of a musical knowledge and the acquisition of singing skills with the lower levels of musical abilities, relying on understanding of musical structure in notational record and motor segment of playing.

The characteristics of the process of learning music that can lead to a distant transfer of musical knowledge and skills on the other cognitive abilities are decoding visual information into motor activity, memorizing and learning musical structures and the rules, learning how to do a fine spectral and temporal 
discrimination and learning of performing fine bimanual movements (Norton et al., 2005).

The primary aim of the research was to determine the attitudes of the students of the Department of Music Art from the Faculty of Arts in Niš according to musical skills acquired in solfeggio teaching, in the context of their impact on the instrumental performance. We have taken on the assumption that the advancement of musical skills acquired in the solfeggio teaching has a positive impact on the field of instrumental performance and leads to the development of musical potential, that is the development od musical skills, both the level of sensory abilities and the level of understanding music structures. We were interested in finding student's perceptions of transferability of musical skills acquired in solfeggio teaching into the framework of instrumental teaching and performance. In order to obtain empirical and quantitative results of research and analysis of student's attitudes, a questionnaire survey was conducted for this occasion with tasks related to the need to determine: student attitude towards the valuation of various components of instrumental performance; correlation of solfeggio and instrumental teaching and the importance of work on certain elements within the solfeggio teaching; towards valuation of expressive elements in relation to the technical skills in the solfeggio teaching. The basic hypothesis relates to the impression that students express a high level of awareness of the close connection between the solfeggio and instrument teaching, equally valuing the work in every area of the solfeggio teaching. They are also aware of the importance of the continuous exercise of expressive elements and technical skills within solfeggio teaching.

\section{MATERIALS AND METHODS}

The research was conducted on a sample $(\mathrm{N}=52)$ of Bachelor students of the Department of Music Art from the Faculty of Arts in Niš. The realization of the research was carried out in November of the academic 2018/2019. year. Among them there were mostly (23/44.2\%) first year students, $16(30.8 \%)$ students of the second year, $12(23.1 \%)$ students of the third year, while the student of the forth year $(1 / 1.9 \%)$ were in the least. The representativeness of the sample was achieved by the choice of several age groups of higher education respondents, and the difference of one year between each group provided an insight into the broader range of the age structure. The research was based on the descriptive method.

For the purposes of the research, a questionnaire, which first part includes questions pertaining to gender, year of the study and the department which students attend, was constructed and applied. The processing of the received data was performed in the statistical package IBM SPSS Statistics 20.0. As far as descriptive statistics are concerned, frequencies (f) and percentages (\%) were used. For statistical analysis purposes a non-parametric Chi-square test was used.

\section{RESULTS}

The first research task was to check the student's opinion on the components that influence the success of the instrumental performance. Deciding on one of the three responses offered - 1 inborn abilities, 2 - acquired abilities, 3 - both, out of the total number of respondents, $46.2 \%$ believe that the successful instrumental performance requires the sharing of inborn and acquired abilities, then the acquired skills $(38.5 \%)$, while the relatively small number of students $(15.4 \%)$ think that effective instrumental performance is influenced by innate abilities (Table 1).

Table 1. Student's attitudes about abilities that influence successful instrumental performance

\begin{tabular}{lrrrr}
\hline & $\begin{array}{c}\text { Inborn } \\
\text { abili- } \\
\text { ties }\end{array}$ & $\begin{array}{c}\text { Ac- } \\
\text { quired } \\
\text { abilities }\end{array}$ & $\begin{array}{c}\text { I agree } \\
\text { with both }\end{array}$ & Total \\
\hline F & 8 & 20 & 24 & 52 \\
P & 15.4 & 38.5 & 46.2 & 100.0 \\
CP & $\mathbf{1 5 . 4}$ & $\mathbf{3 8 . 5}$ & $\mathbf{4 6 . 2}$ & $\mathbf{1 0 0 . 0}$ \\
\hline
\end{tabular}

The results of the Chi-square test (Table 2) show that there is not a significant statistical difference in student's attitudes in relation to the year of study $(\chi 2=5.074 ; d f=6 ; p=0.534)$. 
Table 2. Student's attitudes about abilities that influence successful instrumental performance in relation to the year of study

\begin{tabular}{lccccccccc}
\hline \multicolumn{1}{c}{$\begin{array}{c}\text { Study } \\
\text { year }\end{array}$} & & $\begin{array}{c}\text { Inborn } \\
\text { abilities }\end{array}$ & $\begin{array}{c}\text { Acquired } \\
\text { abilities }\end{array}$ & $\begin{array}{c}\text { I agree } \\
\text { with } \\
\text { both }\end{array}$ & Total & \\
\hline First & 3 & $5.8 \%$ & 11 & $21.1 \%$ & 9 & $17.3 \%$ & 23 & $100.0 \%$ & \\
Second & 2 & $3.8 \%$ & 4 & $7.7 \%$ & 10 & $19.2 \%$ & 16 & $100.0 \%$ & $x^{2}=5.074$ \\
Third & 3 & $5.8 \%$ & 4 & $7.7 \%$ & 5 & $9.6 \%$ & 12 & $100.0 \%$ & $\mathrm{df}=6$ \\
Fourth & 0 & $0.0 \%$ & 1 & $1.9 \%$ & 0 & $0.0 \%$ & 1 & $100.0 \%$ & $\mathrm{p}=0.534$ \\
Total & 8 & $15.4 \%$ & 20 & $38.5 \%$ & 24 & $46.1 \%$ & 52 & $100.0 \%$ & \\
\hline
\end{tabular}

In the second question, students were asked to assess the most valued performance characteristic on scale from 1 to 5 . Features include: expressiveness, personal style, stage performance, technical skills and theoretical knowledge. On the basis of the results obtained, the most evaluated characteristics were: expressiveness $(75.0 \%)$, technical skills $(55.8 \%)$ and personal style $(53.8 \%)$, while the characteristics of minor importance according to the opinion of students are stage performance $(36.5 \%)$ and theoretical knowledge $(25.0 \%)$ (Table 3$)$.

Table 3. Student's attitudes about the evaluation of the performance characteristics

\begin{tabular}{|c|c|c|c|c|c|c|c|c|c|c|c|c|}
\hline & & 1 & & 2 & & 3 & & 4 & & 5 & & Total \\
\hline Expressiveness & 1 & $1.9 \%$ & 2 & $3.8 \%$ & 2 & $3.8 \%$ & 8 & $15.4 \%$ & 39 & $75.0 \%$ & 52 & $100.0 \%$ \\
\hline Personal style & 1 & $1.9 \%$ & 2 & $3.8 \%$ & 8 & $15.4 \%$ & 13 & $25.0 \%$ & 28 & $53.8 \%$ & 52 & $100.0 \%$ \\
\hline $\begin{array}{l}\text { Stage perfor- } \\
\text { mance }\end{array}$ & 1 & $1.9 \%$ & 2 & $3.8 \%$ & 17 & $32.7 \%$ & 13 & $25.0 \%$ & 19 & $36.5 \%$ & 52 & $100.0 \%$ \\
\hline Technical style & 1 & $1.9 \%$ & 1 & $1.9 \%$ & 3 & $5.8 \%$ & 18 & $34.6 \%$ & 29 & $55.8 \%$ & 52 & $100.0 \%$ \\
\hline $\begin{array}{l}\text { Theoretical } \\
\text { knowledge }\end{array}$ & 4 & $7.7 \%$ & 8 & $15.4 \%$ & 14 & $26.9 \%$ & 13 & $25.0 \%$ & 13 & $25.0 \%$ & 52 & $100.0 \%$ \\
\hline
\end{tabular}

Answers to the following question illuminated student's attitudes about the most significant factors that influence the way of interpretation of a musical piece (acquired knowledge and skills, composer's intention, music by itself, character of the piece, personal emotions and feelings), where 1 is very important factor, 2 - not important factor at all, 3 - I might be an important factor. Based on the obtained average values we can notice that students highly evaluate all of the mentioned factors, with minimal difference in percent. Factor acquired knowledge and skills is marked as a very important factor by $88.5 \%$ of respondents, character of the piece $80.8 \%$, music by itself $61.5 \%$, while factors composer's intention and personal emotions are rated as very important factor by $88.5 \%$ of respondents (Table 4). 
Table 4. Student's attitudes about the most significant factors that influence the way of interpretation of a musical piece

\begin{tabular}{|c|c|c|c|c|c|c|c|c|}
\hline & & $\begin{array}{l}\text { Very important } \\
\text { factor }\end{array}$ & & $\begin{array}{l}\text { Not important } \\
\text { factor at all }\end{array}$ & & $\begin{array}{l}\text { It might be an } \\
\text { important } \\
\text { factor }\end{array}$ & & Total \\
\hline $\begin{array}{l}\text { Acquired knowledge } \\
\text { and skills }\end{array}$ & 46 & $88.5 \%$ & 4 & $7.7 \%$ & 2 & $3.8 \%$ & 52 & $100.0 \%$ \\
\hline Composer's intention & 31 & $59.6 \%$ & 6 & $11.5 \%$ & $\begin{array}{l}1 \\
5\end{array}$ & $28.8 \%$ & 52 & $100.0 \%$ \\
\hline Music by itself & 32 & $61.5 \%$ & 4 & $7.7 \%$ & $\begin{array}{l}1 \\
6\end{array}$ & $30.8 \%$ & 52 & $100.0 \%$ \\
\hline Character of the piece & 42 & $80.8 \%$ & 4 & $7.7 \%$ & 6 & $11.5 \%$ & 52 & $100.0 \%$ \\
\hline
\end{tabular}

The next research task was aimed at the information on which components respondents first pay attention to during the first encounter with a melodic exercise. The task offered responses are 1 - melodic line, $2-$ tempo, 3 -dynamics, 4 - time signature, 5 phrasing, 6 - composer. The results in Table 5 show that most of the respondents first pay attention to melodic line $(34.6 \%)$ and time signature (17.3\%). During the first encounter with a melodic exercise $13.5 \%$ of respondents first pay attention to tempo, 5.8\% to phrasing, $3.7 \%$ to composer, while the answer dynamics circled $1.9 \%$ of respondents. Respondents also showed the ability to perceive multiple different components during the first encounter with a melodic exercise. Within multiple responses the melodic line and time signature $(11.5 \%)$ and melodic line, tempo, dynamics and time signature $(9.6 \%)$ were singled out, and a $1.9 \%$ of respondents first pay attention to melodic line and tempo.

Table 5. What is the first thing you pay attention to during the first encounter with a melodic exercise?

\begin{tabular}{lccc}
\hline & $\mathrm{F}$ & $\mathrm{P}$ & $\mathrm{CP}$ \\
\hline Melodic line & 18 & 34.6 & 34.6 \\
\hline Tempo & 7 & 13.5 & 48.1 \\
\hline Dynamics & 1 & 1.9 & 50.0 \\
\hline Time signature & 9 & 17.3 & 67.3 \\
\hline Phrasing & 3 & 5.8 & 73.1 \\
\hline Composer & 2 & 3.8 & 76.9 \\
\hline $\begin{array}{l}\text { Melodic line and time } \\
\text { signature }\end{array}$ & 6 & 11.5 & 88.5 \\
\hline $\begin{array}{l}\text { Melodic line and tempo } \\
\text { Melodic line, tempo, } \\
\text { dynamics and time signature }\end{array}$ & 1 & 1.9 & 90.4 \\
\hline Total & 5 & 9.6 & 100.0 \\
\hline
\end{tabular}

The next question had an aim to examine which area of solfeggio contributes the most to the advancement of instrumental performance. The respondents could circle one or more area from three offered: melodic, rhythm and music theory. Based on the obtained average values it can be seen that respondents believe that melodic and rhythm are the areas that equally contribute to the advancement of instrumental performing (melodic - 48.1\%, rhythm 46.1\%), while for the area music theory opted $5.8 \%$ of respondents (Table 6 ).

Table 6. Student's attitudes about which area of solfeggio contributes the most to the advancement of instrumental performance

\begin{tabular}{lcccc}
\hline & Melodic & Rhythm & Music theory & Total \\
\hline F & 25 & 24 & 3 & 52 \\
\hline P & 48.1 & 46.1 & 5.8 & 100.0 \\
\hline CP & $\mathbf{4 8 . 1}$ & $\mathbf{4 6 . 1}$ & $\mathbf{5 . 8}$ & $\mathbf{1 0 0 . 0}$ \\
\hline
\end{tabular}

The results of the Chi-square test (Table 7) show that there is not a significant statistical difference in student's attitudes in relation to the year of study $(\chi 2=8.531 ; \mathrm{df}=15$; $\mathrm{p}=0.901$ ). 
Table 7. Student's attitudes about which area of solfeggio contributes the most to the advancement of instrumental performance in relation to the year of study

\begin{tabular}{lrrrrrrrrr}
\hline $\begin{array}{c}\text { Study } \\
\text { year }\end{array}$ & & Melodic & & Rhythm & \multicolumn{2}{c}{$\begin{array}{c}\text { Music } \\
\text { theory }\end{array}$} & Total & \\
\cline { 1 - 6 } First & 11 & $21.1 \%$ & 11 & $21.1 \%$ & 1 & $1.9 \%$ & 23 & $100.0 \%$ & \\
Second & 8 & $15.4 \%$ & 7 & $13.5 \%$ & 1 & $1.9 \%$ & 16 & $100.0 \%$ & $x^{2}=8.531$ \\
Third & 5 & $9.6 \%$ & 6 & $11.5 \%$ & 1 & $1.9 \%$ & 12 & $100.0 \%$ & $\mathrm{df}=15$ \\
Fourth & 1 & $1.9 \%$ & 0 & $0.0 \%$ & 0 & $0.0 \%$ & 1 & $100.0 \%$ & $\mathrm{p}=0.901$ \\
\hline Total & $\mathbf{2 5}$ & $\mathbf{4 8 . 1 \%}$ & $\mathbf{2 4}$ & $\mathbf{4 6 . 1 \%}$ & $\mathbf{3}$ & $\mathbf{5 . 8} \%$ & $\mathbf{5 2}$ & $\mathbf{1 0 0 . 0} \%$ & \\
\hline
\end{tabular}

The following question examined the student's opinion on skills of instrumental performance that are advanced in solfeggio teaching. Offered skills are sight reading, performing practiced music, playing by heart, playing by ear and improvisation. Obtained average values show that student's opinion is mostly agreed. Namely, $48.1 \%$ respondents consider that in solfeggio teaching the skill of sight reading is advanced, $17.7 \%$ declared for the answer sight reading and playing by ear, while the skills performing practiced music, playing by ear and sight reading and performing practiced music are included with $7.7 \%$ each (Table 8). Gained results give better insight into student's reflections and their attitude about particular skills that are acquired in solfeggio teaching.

Table 8. Which skills of instrumental performance are advanced in solfeggio teaching?

\begin{tabular}{llll}
\hline & F & P & CP \\
\hline Sight reading & 25 & 48.1 & 48.1 \\
$\begin{array}{l}\text { Performance of } \\
\text { practiced music }\end{array}$ & 4 & 7.7 & 55.8 \\
$\begin{array}{l}\text { Playing by ear } \\
\begin{array}{l}\text { Sight reading and } \\
\text { playing by ear }\end{array}\end{array}$ & 4 & 7.7 & 63.5 \\
$\begin{array}{l}\text { Sight reading and } \\
\text { performance of }\end{array}$ & 4 & 7.7 & 88.5 \\
practiced music & & & \\
$\begin{array}{l}\text { All mentioned } \\
\text { Total }\end{array}$ & 6 & 11.5 & 100.0 \\
\hline
\end{tabular}

The next research task was aimed to determine the student's attitudes about the importance of work on some elements in the framework of solfeggio teaching. Within these questions students showed their attitude by choosing one of a five offered statements (very important-1, important, but not crucial - 2, classes can be carried out without this segment/can be excluded-3, not important at all - 4, I have no opinion - 5).

First question within this research task examined the student's attitudes about the importance of work on melodic. Based on the obtained average values, the respondents highly evaluated work on melodic. Out of a total number of respondents $53.8 \%$ consider the work on melodic very important, $42.3 \%$ agrees with the statement that work on melodic is important, but it is not of a crucial importance, while only $3.8 \%$ believe that solfeggio teaching classes can be carried out without this segment (Table 9).

Table 9. Student's attitudes about the importance of work on melodic

\begin{tabular}{lcccccc}
\hline & $\begin{array}{c}\text { Very } \\
\text { important }\end{array}$ & $\begin{array}{c}\text { Important, but } \\
\text { not crucial }\end{array}$ & $\begin{array}{c}\text { Can be } \\
\text { excluded }\end{array}$ & $\begin{array}{c}\text { Not } \\
\text { important } \\
\text { at all }\end{array}$ & $\begin{array}{c}\text { I have } \\
\text { no } \\
\text { opinion }\end{array}$ & Total \\
\hline F & 28 & 22 & 2 & 0 & 0 & 52 \\
\hline P & 53.8 & 42.3 & 3.8 & 0.0 & 0.0 & 100.0 \\
\hline CP & $\mathbf{5 3 . 8}$ & $\mathbf{9 6 . 2}$ & $\mathbf{3 . 8}$ & $\mathbf{0 . 0}$ & $\mathbf{0 . 0}$ & $\mathbf{1 0 0 . 0}$ \\
\hline
\end{tabular}

By comparing data with a variable Year of study, and based on the results of Chi-square test we can notice that there is not a significant statistical difference in student's attitudes in relation to the year of study $(\chi 2=7.227 ; \mathrm{df}=6$; $\mathrm{p}=0.300)$. No matter what, it can be seen that the answer can be excluded was chosen by students of first and second study year, which confirms the fact that attitudes are positively changing with the age. 
Table 10. Student's attitudes about the importance of work on melodic in relation to the year of study

\begin{tabular}{|c|c|c|c|c|c|c|c|c|c|c|c|c|c|}
\hline $\begin{array}{l}\text { Study } \\
\text { year }\end{array}$ & & $\begin{array}{c}\text { Very } \\
\text { important }\end{array}$ & & $\begin{array}{l}\text { Important, } \\
\text { but not } \\
\text { crucial }\end{array}$ & & $\begin{array}{l}\text { It can be } \\
\text { excluded }\end{array}$ & & $\begin{array}{c}\text { Not } \\
\text { important at } \\
\text { all }\end{array}$ & & $\begin{array}{l}\text { I have no } \\
\text { opinion }\end{array}$ & & Total & \\
\hline First & 9 & $17.31 \%$ & 13 & $25.0 \%$ & 1 & $1.9 \%$ & 0 & $0.0 \%$ & 0 & $0.0 \%$ & 23 & $100.0 \%$ & \\
\hline Second & 12 & $23.1 \%$ & 3 & $5.8 \%$ & 1 & $1.9 \%$ & 0 & $0.0 \%$ & 0 & $0.0 \%$ & 16 & $100.0 \%$ & $\mathrm{x}^{2}=7.227$ \\
\hline Third & 6 & $11.5 \%$ & 6 & $11.5 \%$ & 0 & $0.0 \%$ & 0 & $0.0 \%$ & 0 & $0.0 \%$ & 12 & $100.0 \%$ & $\mathrm{~d} \mathrm{f}=6$ \\
\hline Fourth & 1 & $1.9 \%$ & 0 & $0.0 \%$ & 0 & $0.0 \%$ & 0 & $0.0 \%$ & 0 & $0.0 \%$ & 1 & $100.0 \%$ & $\mathrm{p}=0.300$ \\
\hline Total & 28 & $53.9 \%$ & 22 & $42.3 \%$ & 2 & $3.8 \%$ & 0 & $0.0 \%$ & 0 & $0.0 \%$ & 52 & $100.0 \%$ & \\
\hline
\end{tabular}

In the framework of the work on melodic, a question was raised regarding the attitude of the students about the importance of performing prima vista examples. Students recognize the importance of practicing these examples and highly value this segment of teaching, as evidenced by the following results: very important - $32.7 \%$, important, but not crucial - 55.8\%, it can be excluded $-5.8 \%$, not important at all $-1.9 \%$, I have no opinion $-3.8 \%$ (Table 11).

Table 11. Student's attitudes about the importance of performing prima vista examples

\begin{tabular}{lcccccc}
\hline & $\begin{array}{c}\text { Very } \\
\text { important }\end{array}$ & $\begin{array}{c}\text { Important, } \\
\text { but not } \\
\text { crucial }\end{array}$ & $\begin{array}{c}\text { It can be } \\
\text { excluded }\end{array}$ & $\begin{array}{c}\text { Not } \\
\text { important } \\
\text { at all }\end{array}$ & $\begin{array}{c}\text { I have } \\
\text { no } \\
\text { opinion }\end{array}$ & Total \\
\hline F & 17 & 29 & 3 & 1 & 2 & 52 \\
\hline P & 32.7 & 55.8 & 5.8 & 1.9 & 3.8 & 100.0 \\
\hline CP & $\mathbf{3 2 . 7}$ & $\mathbf{8 8 . 5}$ & $\mathbf{9 4 . 2}$ & $\mathbf{9 6 . 2}$ & $\mathbf{1 0 0 . 0}$ & $\mathbf{1 0 0 . 0}$ \\
\hline
\end{tabular}

Work on rhythm (Table 12) was also highly evaluated by respondents (very important $92.3 \%$, important, but not crucial $7.7 \%)$.

Table 12. Student's attitudes about the importance of work on rhythm

\begin{tabular}{lcccccc}
\hline & $\begin{array}{c}\text { Very } \\
\text { important }\end{array}$ & $\begin{array}{c}\text { Important, } \\
\text { but not } \\
\text { crucial }\end{array}$ & $\begin{array}{c}\text { It can be } \\
\text { excluded }\end{array}$ & $\begin{array}{c}\text { Not } \\
\text { important } \\
\text { at all }\end{array}$ & $\begin{array}{c}\text { I have } \\
\text { no } \\
\text { opinion }\end{array}$ & Total \\
\hline F & 48 & 4 & 0 & 0 & 0 & 52 \\
\hline P & 92.3 & 7.7 & 0.0 & 0.0 & 0.0 & 100.0 \\
\hline CP & $\mathbf{9 2 . 3}$ & $\mathbf{1 0 0 . 0}$ & $\mathbf{0 . 0}$ & $\mathbf{0 . 0}$ & $\mathbf{0 . 0}$ & $\mathbf{1 0 0 . 0}$ \\
\hline
\end{tabular}

With the next question we were overwhelmed on rhythm area by questioning student's attitudes about the performance ability that they consider to be the most related to work on rhythm within solfeggio teaching. The respondents expressed their attitudes by rounding off one or more abilities from five offered: steady beat, ability to adapt to the set tempo, reaction to changing tempo, proper performance of certain rhythmic figures and species and ability of moderate and thoughtful agogic shading. Based on the obtained average values it was determined that almost half out of a total number of respondents selected the answer proper performance of certain rhythmic figures and species (44.2\%), 23.1\% steady beat $19.2 \%$ respondents selected multiply answer uniform pulsation and proper performance of certain rhythmic figures and species. So, most of them believe that solfeggio teaching advances primary these two abilities. Ability of moderate and thoughtful agogic shading was chosen by $5.8 \%$ respondents, while $3.8 \%$ of them consider that within solfeggio teaching advances the ability to adapt to the set tempo and ability of reaction to changing tempo (Chart 1).

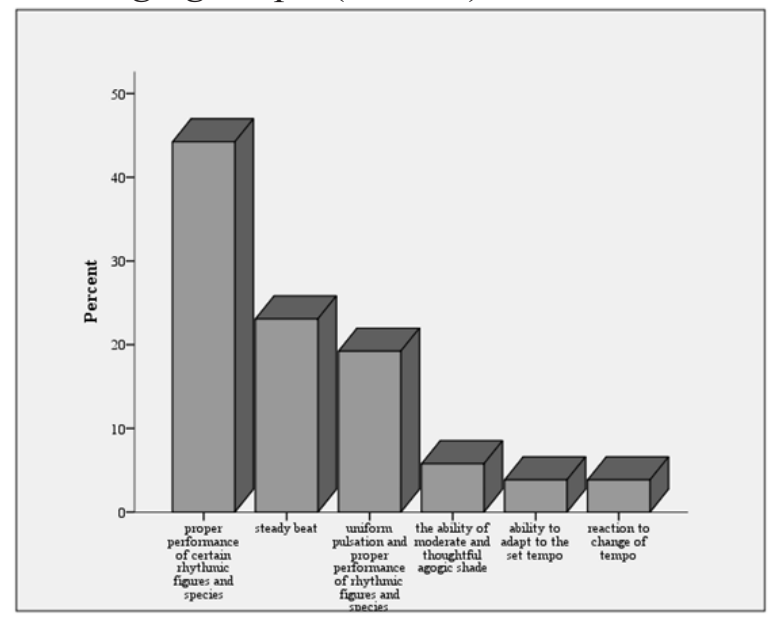

Chart 1. Which performance ability you consider to be the most related to work on rhythm within solfeggio teaching?

Based on the analysis of the obtained average values for questions concerning the importance of manual performing exercises by taping, singing melodic with the taping of a rhythmic section, and the work on two-handed taping, we realize that respondents agree that these teaching segments are important, but that they are not of crucial importance (Table 13). 
Table 13. Student's attitudes about the importance of work on certain segments in the rhythm area

\begin{tabular}{lcccccc}
\hline \multicolumn{6}{c}{ Student's attitudes about the importance of manual performing rhythmic exercises by taping } \\
\hline $\begin{array}{l}\text { Very im- } \\
\text { portant }\end{array}$ & $\begin{array}{c}\text { Important, } \\
\text { but not cru- } \\
\text { cial }\end{array}$ & $\begin{array}{c}\text { It can be } \\
\text { excluded }\end{array}$ & $\begin{array}{c}\text { Not im- } \\
\text { portant at } \\
\text { all }\end{array}$ & $\begin{array}{c}\text { I have no } \\
\text { opinion }\end{array}$ & Total \\
\hline F & 11 & 24 & 13 & 1 & 3 & 52 \\
P & 21.2 & 46.2 & 25.0 & 1.9 & 5.8 & 100.0 \\
CP & $\mathbf{2 1 . 2}$ & $\mathbf{6 7 . 3}$ & $\mathbf{9 2 . 3}$ & $\mathbf{9 4 . 2}$ & $\mathbf{1 0 0 . 0}$ & $\mathbf{1 0 0 . 0}$ \\
\hline
\end{tabular}

Student's attitudes about the importance of work on singing melodic with the taping of a rhythmic section

\begin{tabular}{lllllll}
\hline F & 9 & 22 & 18 & 2 & 1 & 52 \\
P & 17.3 & 42.3 & 34.6 & 3.8 & 1.9 & 100.0 \\
$\mathbf{C P}$ & $\mathbf{1 7 . 3}$ & $\mathbf{5 9 . 6}$ & $\mathbf{9 4 . 2}$ & $\mathbf{9 8 . 1}$ & $\mathbf{1 0 0 . 0}$ & $\mathbf{1 0 0 . 0}$ \\
\hline \multicolumn{5}{l}{ Student's attitudes about the importance of work on two-handed taping } \\
\hline F & 6 & 18 & 23 & 2 & 3 & 52 \\
P & 11.5 & 34.6 & 44.2 & 3.8 & 5.8 & 100.0 \\
CP & $\mathbf{1 1 . 5}$ & $\mathbf{4 6 . 2}$ & $\mathbf{9 0 . 4}$ & $\mathbf{9 4 . 2}$ & $\mathbf{1 0 0 . 0}$ & $\mathbf{1 0 0 . 0}$ \\
\hline
\end{tabular}

The next question referred to the area of work on dictations. Based on the results on importance of work on melodic dictations it can be seen that students highly evaluate this segment of work, since $57.7 \%$ respondents consider this segment as a very important. Besides, attitudes have been agreed, so study year does not have statistical significance or impact to the final result (Tables 14 and 15).
Table 14. Student's attitudes about the importance of work on melodic dictations

\begin{tabular}{lcccccc}
\hline & $\begin{array}{c}\text { Very } \\
\text { important }\end{array}$ & $\begin{array}{c}\text { Important, } \\
\text { but not } \\
\text { crucial }\end{array}$ & $\begin{array}{c}\text { It can be } \\
\text { excluded }\end{array}$ & $\begin{array}{c}\text { Not } \\
\text { important } \\
\text { at all }\end{array}$ & $\begin{array}{c}\text { I have } \\
\text { no } \\
\text { opinion }\end{array}$ & Total \\
\hline F & 30 & 16 & 3 & 0 & 3 & 52 \\
\hline P & 57.7 & 30.8 & 5.8 & 0.0 & 5.8 & 100.0 \\
\hline CP & $\mathbf{5 7 . 7}$ & $\mathbf{8 8 . 5}$ & $\mathbf{9 4 . 2}$ & $\mathbf{0 . 0}$ & $\mathbf{1 0 0 . 0}$ & $\mathbf{1 0 0 . 0}$ \\
\hline
\end{tabular}

Table 15. Student's attitudes about the importance of work on melodic dictations in relation to the year of study

\begin{tabular}{|c|c|c|c|c|c|c|c|c|c|c|c|c|c|}
\hline Study year & & $\begin{array}{c}\text { Very } \\
\text { important }\end{array}$ & & $\begin{array}{c}\text { Important, } \\
\text { but not } \\
\text { crucial }\end{array}$ & & $\begin{array}{l}\text { It can be } \\
\text { excluded }\end{array}$ & & $\begin{array}{l}\text { Not } \\
\text { important } \\
\text { at all }\end{array}$ & & $\begin{array}{c}\text { I have } \\
\text { no } \\
\text { opinion }\end{array}$ & & Total & \\
\hline First & 14 & $26.9 \%$ & 4 & $7.7 \%$ & 2 & $3.8 \%$ & 0 & $0.0 \%$ & 3 & $5.8 \%$ & 23 & $100.0 \%$ & \\
\hline Second & 10 & $19.2 \%$ & 6 & $11.5 \%$ & 0 & $0.0 \%$ & 0 & $0.0 \%$ & 0 & $0.0 \%$ & 16 & $100.0 \%$ & $x^{2}=9.514$ \\
\hline Third & 5 & $9.6 \%$ & 6 & $11.5 \%$ & 1 & $1.9 \%$ & 0 & $0.0 \%$ & 0 & $0.0 \%$ & 12 & $100.0 \%$ & $\mathrm{df}=9$ \\
\hline Fourth & 1 & $1.9 \%$ & 0 & $0.0 \%$ & 0 & $0.0 \%$ & 0 & $0.0 \%$ & 0 & $0.0 \%$ & 1 & $100.0 \%$ & $\mathrm{p}=0.391$ \\
\hline Total & 30 & $57.7 \%$ & 16 & $30.1 \%$ & 3 & $5.8 \%$ & 0 & $0.0 \%$ & 3 & $5.8 \%$ & 52 & $100.0 \%$ & \\
\hline
\end{tabular}

When it comes to the rhythmic dicta- tations is important, but not crucial (Table 16). tions, average values show lower evaluating of this segment, since half of respondents expressed the opinion that work on rhythmic dic- 
Table 16. Student's attitudes about the importance of work on rhythmic dictations

\begin{tabular}{lcccccc}
\hline & $\begin{array}{c}\text { Very } \\
\text { important }\end{array}$ & $\begin{array}{c}\text { Important, } \\
\text { but not } \\
\text { crucial }\end{array}$ & $\begin{array}{c}\text { It can be } \\
\text { excluded }\end{array}$ & $\begin{array}{c}\text { Not } \\
\text { important } \\
\text { at all }\end{array}$ & $\begin{array}{c}\text { I have } \\
\text { no } \\
\text { opinion }\end{array}$ & Total \\
\hline F & 14 & 26 & 7 & 1 & 4 & 52 \\
\hline P & 26.9 & 50.0 & 13.5 & 1.9 & 7.7 & 100.0 \\
\hline CP & $\mathbf{2 6 . 9}$ & $\mathbf{7 6 . 9}$ & $\mathbf{9 0 . 4}$ & $\mathbf{9 2 . 3}$ & $\mathbf{1 0 0 . 0}$ & $\mathbf{1 0 0 . 0}$ \\
\hline
\end{tabular}

Evaluating the importance of work on improvisation and practicing examples from artistic literature, respondents highly evaluated first segment, but believing that it is not of a crucial importance (Table 17), while work on examples from artistic literature is valued as a very important segment by $46.2 \%$ respondents (Table 18), which is in accordance with the study program they attend.

Table 17. Student's attitudes about the importance of work on improvisation

\begin{tabular}{lcccccc}
\hline & $\begin{array}{c}\text { Very } \\
\text { important }\end{array}$ & $\begin{array}{c}\text { Important, } \\
\text { but not } \\
\text { crucial }\end{array}$ & $\begin{array}{c}\text { It can be } \\
\text { excluded }\end{array}$ & $\begin{array}{c}\text { Not } \\
\text { important } \\
\text { at all }\end{array}$ & $\begin{array}{c}\text { I have } \\
\text { no } \\
\text { opinion }\end{array}$ & Total \\
\hline F & 8 & 27 & 12 & 3 & 2 & 52 \\
\hline P & 15.4 & 51.9 & 23.1 & 5.8 & 3.8 & 100.0 \\
\hline CP & $\mathbf{1 5 . 4}$ & $\mathbf{6 7 . 3}$ & $\mathbf{9 0 . 4}$ & $\mathbf{9 6 . 2}$ & $\mathbf{1 0 0 . 0}$ & $\mathbf{1 0 0 . 0}$ \\
\hline
\end{tabular}

Table 18. Student's attitudes about the importance of work on examples from artistic literature

\begin{tabular}{lcccccc}
\hline & $\begin{array}{c}\text { Very } \\
\text { important }\end{array}$ & $\begin{array}{c}\text { Important, } \\
\text { but not } \\
\text { crucial }\end{array}$ & $\begin{array}{c}\text { It can be } \\
\text { excluded }\end{array}$ & $\begin{array}{c}\text { Not } \\
\text { important } \\
\text { at all }\end{array}$ & $\begin{array}{c}\text { I have } \\
\text { no } \\
\text { opinion }\end{array}$ & Total \\
\hline F & 24 & 15 & 11 & 1 & 1 & 52 \\
\hline P & 46.2 & 28.8 & 21.2 & 1.9 & 1.9 & 100.0 \\
\hline CP & $\mathbf{4 6 . 2}$ & $\mathbf{7 5 . 0}$ & $\mathbf{9 6 . 2}$ & $\mathbf{9 8 . 1}$ & $\mathbf{1 0 0 . 0}$ & $\mathbf{1 0 0 . 0}$ \\
\hline
\end{tabular}

The last research task referred to evaluating expressive elements in relation to technical skills within solfeggio teaching (Table 19). On question Do you, within solfeggio teaching, give the advantage to: 1 -expressive elements, 2 - technical skills, 3 -I have no opinion, 4 - expressive elements and technical skills? half of them gave equal importance to both of the abilities, which supports the claim that students at this level of study have a developed awareness of the importance of linking the technique and expression.

Table 19. Expressive elements or technical skills?

\begin{tabular}{lcccccc}
\hline & $\begin{array}{c}\text { Very } \\
\text { important }\end{array}$ & $\begin{array}{c}\text { Important, } \\
\text { but not } \\
\text { crucial }\end{array}$ & $\begin{array}{c}\text { It can be } \\
\text { excluded }\end{array}$ & $\begin{array}{c}\text { Not } \\
\text { important } \\
\text { at all }\end{array}$ & $\begin{array}{c}\text { I have } \\
\text { no } \\
\text { opinion }\end{array}$ & Total \\
\hline F & 8 & 11 & 7 & 26 & 52 & 8 \\
\hline P & 15.4 & 21.2 & 13.5 & 50.0 & 100.0 & 15.4 \\
\hline CP & $\mathbf{1 5 . 4}$ & $\mathbf{3 6 . 5}$ & $\mathbf{5 0 . 0}$ & $\mathbf{1 0 0 . 0}$ & $\mathbf{1 0 0 . 0}$ & $\mathbf{1 5 . 4}$ \\
\hline
\end{tabular}

\section{DISCUSSIONS}

Our research has studied student's attitudes about possible reflection of the solfeggio teaching content and skills acquired within it.

Students' opinion on the components that affect the success of an instrumental performance (almost half of them believe that successful instrumental performance requires sharing of innate and acquired abilities) speaks to their awareness that talent is an important factor, but that continuous acquisition and mastering skills is necessary for successful performance (Table 1).

One reads from Table 2 that there is not a significant statistical difference in student's attitudes in relation to the year of study, which implies that students at all levels of the study are aware that inborn abilities affect the instrumental performance, but that success undoubtedly depends on the acquired skills as well.

The results from Table 3 show that students' attitudes are in line with the study program they attend.

From Table 4 we can conclude that respondents at this level of knowledge express a high level of awareness of the importance of different factors and characteristics and their impact on successful instrumental performance.

The fact that students highly evaluate all of the mentioned factors that influence the way of interpretation of a musical piece (Table 4) undoubtedly indicates that students at this level of education are aware of the delicacy of instrumental performance, which depends on the synergy of many factors.

By analyzing Table 5 we find that during the first encounter with melodic exercise most of the students first pay attention to the melody line $(34.6 \%)$ and time signature $(17.3 \%)$, which is important information about their perception experience. We think that these attitudes were influenced by prior schooling, in which the habit of simultaneously observing multiple components is not sufficiently developed.

Tables 6 and 7 show that students place theory in a subordinate position relative to practice, without statistical significance in relation to the year of study. In their view melodic $(48.1 \%)$ and rhythm (46.1\%) are the areas that equally contribute to the advancement of instrumental performing, while for the area music theory opted $5.8 \%$ of respondents.

Based on the results from Table 8 we can se that students agree that within solfeg- 
gio teaching advances the skill of sightreading. The results also show the awareness of respondents about the importance of correlation of instrumental performance with solfeggio teaching and their pervasion.

In the next research task students expressed their attitudes about the importance of work on some elements in the framework of solfeggio teaching. Students showed positive attitudes towards work on some elements in the framework of solfeggio teaching (Tables 9-18). The answers of evaluation were mostly either Very important or Important, but not crucial. Positive attitudes confirm the initial hypothesis and provide insight into teaching practice.

The results from the last research task, which referred to evaluating expressive elements in relation to technical skills within solfeggio teaching (Table 19) reaffirm the importance of the need for synergy of expressive elements and technical skills and student's awareness of it.

The overall results confirm the hypothesis that students express high awareness of the narrow connectivity of solfeggio and instrumental teaching, equally evaluating work in all areas of solfeggio teaching. They also showed positive attitudes about a possible reflection of the solfeggio teaching content and skills that are acquired in it, as well as there's a high degree of the use of skill acquired in solfeggio teaching in instrumental performance.

\section{CONCLUSIONS}

This paper presents the results of a descriptive pilot study in which quantitative and qualitative analysis was used. Research results indicate the importance of educational experience in shaping the attitudes of students. Students have shown positive attitudes about the possible reflection of the solfeggio teaching content and skills acquired within it, and based on the data analysis it has been found that there is a high degree of use of skills acquired in solfeggio teaching in instrumental performance. The present findings confirmed the actuality of the topic, which is the subject of constant discussions at the level of curriculum and the realized cooperation between solfeggio and instrument teachers. The general conclusion is reduced to the need for a transfer to exist in all domains of musical skills that are represented in solfeggio teaching, while the aims of solfeggio teaching must be set so that they are not isolated and self-sufficient, but precisely contribute to the development in the field of instrumental music performance. Transfer of learning as one of the basic aims of education must not be adrift. The issue of transferring musical skills from the teaching and linking with the development of the skills of performing demands the joint, cooperative work of teachers and students, which further implies curriculum alignment as an important area for further consideration. For a better understanding of learning transfer and a more complete realization of musical potential, it is essential to extend musical education to the level at which its differentiated activities become integrated in such a way that each of them has the function of empowering others. In this way, the correlation of solfeggio teaching with instrumental education has a prominent role at all levels of music education. It is not meant exclusively for the harmonization of curricula and forcing the study of the theory, but for thinking about vocal and instrumental practice as one discipline.

In order to train students at all levels for quality interpreting and supporting their musical and personal development, contemporary solfeggio teaching must put students in an active relationship with the music they will be able to perform independently. This highlights the role of teachers in the attainment of skills and competences (Bogunović and Mirović, 2014). The significance of properly defined and applied teacher competencies represents a solid foundation for the successful achievement of educational goals and objectives (Nikodinovska Bancotovska, 2015). This research represents a small group effort within the solfeggio teaching of students of Performing Arts at Faculty of Arts of the University in Niš, and is a prerequisite for further research in this field. The incentive and support for this kind of research came from the students themselves, and the research itself has provided practical implications in the process of music education of students, and brought new insights into the subject.

\section{ACKNOWLEDGEMENTS}

The paper is the part of the project of Niš Branch of the Serbian Academy of Sciences and Arts (SASA): 0-10-17 "The Music Heritage of Southeast Serbia, Contemporary Creativity and the Formation of Taste".

\section{Conflict of interests}

The authors declare no conflict of interest. 


\section{REFERENCES}

Beck, A., Surmani, K., and Lewis, B. (2004). Sing at first sight. Van Nuys, CA: Alfred Publishing Co., Inc. In: A. B. Klemp, The effects of instrumental training on the music notation reading abilities of high school choral musicians. Doctoral dissertation, New Jersey: Mason Gross School of the Arts Rutgers, The State University of New Jersey. Retrieved from https://rucore.libraries. rutgers.edu/rutgers-lib/26699/PDF/1/play/

Bogunović, B. \& Mirović, T. (2014). Visoko obrazovanje muzički darovitih: studentske procene kompetencija nastavnika. [Musically Gifted Higher Education: Student Assessments of Teachers' Competencies] Primenjena psihologija 7(3), Tematski broj: Postignuća učenika, 469-491. https://doi.org/10.19090/pp.2014.3.469-491

Bogunović, B. \& Vujović, I. (2012). Metacognitive Strategies in Learning Sight-Singing. Psihološka istraživanja, Vol. XV(2), 115-133. Retrieved from https://www.researchgate.net/ publication/272477251_Metacognitive_Strategies in Learning Sight-Singing

Cvetković Črvenica J. \& Miletić, Đ. A. (2019). Obrazovne implikacije potencijalnog uticaja transfera učenja u oblasti muzičkog obrazovanja. [Educational implications of the potential impact of learning transfer in the field of music education]. Vlado S. Milošević: etnomuzikolog, kompozitor i pedagog. TRADICIJA KAO INSPIRACIJA tematski zbornik sa naučnog skupa, Banja Luka: Akademija umjetnosti Univerziteta u Banjoj Luci, Akademija nauka i umjetnosti Republike Srpske, Muzikološko društvo Republike Srpske, 205-221. ISBN978-99938-27-28-3 (AUBL). COBISS.RS-ID 8052248. CIP - 781.7 (082); 78.072(082).

Cvetković-Crvenica, J. D. (2017). Inner pitch and reception in contemporary pedagogy: Fostering and development. Godišnjak Pedagoškog fakulteta u Vranju, 8(2), 283-298. https://doi. org/10.5937/gufv1702283C

Galustyan, O. V. (2017). Some methodological aspects of the evaluation of students'educational achievements at university. International Journal of Cognitive Research in Science, Engineering and Education, 5(1), 43-48. https://doi. org/10.5937/IJCRSEE1701043G

Hallam, S. (2006). Conceptions of Musical Ability. Research Studies in Music Education 20(1), 425 433. Retrieved from https://www.researchgate. net/publication/228983374_Conceptions_of_ Musical Ability

Haskell, R. E. (2001). Transfer of learning: Cognition, Instruction, and Reasoning. Educational Psychology, 23-29. http://dx.doi.org/10.1016/B978012330595-4/50003-2

Klemp, B. A. (2010). The effects of instrumental training on the music notation reading abilities of high school choral musicians (Doctoral dissertation, Rutgers University-Mason Gross School of the Arts). https://doi.org/doi:10.7282/ T3474B0D

McPherson, G. E. (1997). Cognitive Strategies and Skill Acquisition in Musical Performance. Bulletin of the Council for Research in $\mathrm{Mu}$ sic Education, 133, 64-71. Retrieved from https://www.jstor.org/stable/40318841?read- now $=1 \&$ seq $=1 \#$ page scan tab contents

Nikodinovska Bancotovska, S. (2015). The attitudes and opinions of teachers to their competences. International Journal of Cognitive Research in Science, Engineering and Education, 3(1). 99103. Retrieved from http://ijcrsee.com/index. php/ijcrsee/article/view/120

Norton, A., Winner, E., Cronin, K., Overy, K., Lee, D. J., \& Schlaug, G. (2005). Are there pre-existing neural, cognitive, or motoric markers for musical ability?. Brain and cognition, 59(2), 124-134. https://doi.org/10.1016/j.bandc.2005.05.009

Peričić, V., \& Stefanović, D. I. (1985). Višejezični rečnik muzičkih termina [A multilingual dictionary of musical terms] (Vol. 563). SANU.

Sala, G., \& Gobet, F. (2017). When the music's over. Does music skill transfer to children's and young adolescents' cognitive and academic skills? A meta-analysis. Educational Research Review, 20, 55-67. https://doi.org/10.1016/j. edurev.2016.11.005

Schellenberg, E. G. (2004). Music lessons enhance IQ. Psychological science, 15(8), 511-514. https:// doi.org/10.1111/j.0956-7976.2004.00711.x

Stauffer, D. (2005). Learning to read music fluently. Music Educators Journal, 92(1), 21-22. Retrieved from https://journals.sagepub.com/doi/ pdf $/ 10.2307 / 3400211$

Tsankov, N. (2017). Development of transversal competences in school education (a didactic interpretation). International Journal of Cognitive Research in Science, Engineering and Education (IJCRSEE), 5(2), 129-144. https:// doi.org/10.5937/IJCRSEE1702129T 